Dr. de Rode has had exceptional opportunities of observing the influence of the system on the mental health of the prisoners.

After referring to the earlier statistics bearing on the question, and pointing out their conflicting character owing to local and other limitations, the paper deals with the evidence of recent Belgian experience. Taking the central (convict) prisons, it appears that during the eight years $1891-8$ the proportion of prisoners becoming insane averaged $\mathrm{I}^{\circ} 58$ per cent. in Louvain, where the separate system is in force; while in Gand, under the associated system, it averaged $3.5^{\circ}$ per cent. Some of the prisoners becoming insane in Gand, however, had undergone separate confinement before they were placed in association. In the secondary prisons for minor offenders the number of cases of insanity was much lower.

A table gives details regarding all the prisoners found insane on examination by the consultants ; these details concern age, antecedents, crime, and period of detention before development of insanity. Other tables give similar details (referring to the years 1896-8) for prisoners relieved from separate confinement, and placed in association on account of mental symptoms.

Taking all the prisons of the country together, it appears that on an average 3.32 per cent. of the prisoners in cellular confinement are brought to the special notice of the alienist inspectors ; in 1 '09 per cent. the prisoners are found insane and sent to asylums, and in ${ }^{\circ} 5^{8}$ per cent. their separate confinement is discontinued.

The author concludes from his observations that there is no such thing as a special "prison insanity," the psychoses occurring in prisoners being the same as those developed elsewhere; that the number of cases of insanity under the separate system is not at all, or is only very slightly, above that found in the associated system; and that even this small number might be further reduced by a process of selection which should exclude prisoners mentally unstable.

W. C. Sullivan.

Part IV.-Notes and News.

MEDICO.PSYCHOLOGICAL ASSOCIATION OF GREAT BRITAIN AND IRELAND.

General Meeting.

Minutes of the General Meeting held at the London County Asylum, Claybury, Woodford, Essex, on Thursday, February 14th, 1901.

Present: Drs. Fletcher Beach (President), H. Hayes Newington (Treasurer), A. R. Urquhart, J. Wiglesworth, A. W. Campbell, H. A. Benham (Registrar), J. Carlyle Johnstone, F. A. Elkins, A. N. Boycott, H. T. S. Aveline, L. A. Weatherly, F. H. Edwards, J. Peeke Richards, R. Percy Smith, J. R. Whitwell, R. H. Steen, J. McConaghey, Bedford Pierce, Charles Caldecott, J. F. Briscoe, S. R. Macphail, Walter S. Kay, H. Gardiner Hill, J. R. Hill, George O. Hughes, Eric France, Reginald H. Noott, J. S. Bolton, John C. Anderson, Rosina C. Despard, J. J. 
Murphy, Evan Powell, George Amsden, H. E. Haynes, H. Kerr, L. S. Morrison, G. Stanley Elliot, A. S. Newington, G. K. Hitchcock, James Chambers, H. Corner, T. Outterson Wood, T. Seymour Tuke, David Fleck, C. T. Ewart, Emily Dove, Alice H. Boyle, N. H. Macmillan, A. H. Spicer, G. E. Mould, and Robert Jones (Secretary).

Visitors: Rev. R. D. Swallow, Rev. T. Marsden, Rev. F. Mann, Professor W. D. Halliburton, Drs. N. Macleod, G. G. Younger, Messrs. Percy B. Simpson and W. C. Clifford Smith.

Apologies were received from-Drs. Savage, Crochley Clapham, Bond, Rayner, Rolleston, D. Hunter, T. Oscar Woods, Mercier, Douglas, Thompson, LangdonDown, Gilfillan, Miller, Spence, Finegan, Ernest W. White, P. W. Macdonald, and $A$. R. Turnbull.

The President referred in graceful and well-chosen words to the lamented death of the late Sovereign Queen Victoria, and read the address which appears on pages 224 and 225, and which the Council recommended to be sent through the Home Secretary to His Majesty the King. Members, all standing, unanimously agreed that the address be suitably engrossed on vellum, and presented as recommended by the Council.

The following candidates were balloted for and elected members of the Association:-James Anderson, Samuel Charles Elgee, William Erskine, James William Evans, William George Fee, C. H. G. Gostwyck, Mary Baird Hannay, Neil Macleod, Alexander Simpson, Robert Pugh, and Arthur Sykes.

The President called upon Mr. Clifford Smith, Engineer to the Asylums Committee, to demonstrate the plans of the proposed epileptic colony, to be built on the Horton Estate, Epsom, by the London County Council, and designed by him on the lines suggested by Dr. G. J. Cooper, L.C.C., in his report upon "A Scheme for the Establishment of an Epileptic Colony."

A paper, prepared by Dr. G. J. Cooper, illustrating the scheme, was read by the SECRETARY in the author's absence, and will appear in the next number of the JOURNAL.

Dr. Wiglesworth read a paper upon "A Case of Murder, the Result of Pure Homicidal Impulse" (see page 335).

\section{Chemistry of Nerve Degeneration.}

Professor HAlliburton, F.R.S., made the following preliminary communication on the "Chemistry of Nerve Degeneration." The work had been carried out in conjunction with Dr. Mott, who was unavoidably prevented by illness from making the communication himself :

We have previously shown that in the disease general paralysis of the insane, the marked degeneration that occurs in the brain is accompanied by the passing of the products of degeneration into cerebro-spinal fluid. Of these nucleo-proteid and choline are those which can be most readily detected. Choline can also be found in the blood. We have continued this work, and we find that this is not peculiar to the disease just mentioned, but that in various other degenerative nervous diseases (combined sclerosis, disseminated sclerosis, alcoholic neuritis, beri-beri) choline can also be detected in the blood. The tests we have employed to detect choline are mainly two: (1) a chemical test, namely, the obtaining of the characteristic octahedral crystals of the platinum double salt from the alcoholic extract of the blood; (2) a physiological test namely, the lowering of blood-pressure (partly cardiac in origin, and partly due to dilatation of peripheral vessels) which a saline solution of the residue of the alcoholic extract produces; this fall is abolished, or even replaced by a rise of arterial pressure, if the animal has been atropinised. It is possible that such tests may be of diagnostic value in the distinction between organic and so-called functional diseases of the nervous system. The chemical test can frequently be obtained with 10 c.c. of blood.

A similar condition was produced artificially in cats by a division of both sciatic nerves; and is most marked in those animals in which the degenerative process is at its height as tested histologically by the Marchi reaction. A chemical analysis of the nerves themselves was also made. A series of eighteen cats was taken, both sciatic nerves divided, and the animals subsequently killed at intervals varying from 2 to 106 days. The nerves remain practically normal as long as 
they remain irritable; this is up to three days after the operation. They then show a progressive increase in the percentage of water, and a progressive decrease in the percentage of phosphorus until degeneration is complete. When regeneration occurs, the nerves turn approximately to their previous chemical condition. The chemical explanation of the Marchi reaction appears to be the replacement of phosphorised by non-phosphorised fat. When the Marchi reaction disappears in the later stages of degeneration, the non-phosphorised fat has been absorbed. This absorption occurs earlier in the peripheral nerves than in the central nervous system.

Specimens, tables, and lantern slides illustrating the correspondence of chemical and histological changes in the nerves were shown to the meeting.

This confirms previous observations by Mott and Barratt in the spinal cord, in which unilateral degeneration of the pyramidal tract by brain lesions produced an increase of water and a diminution of phosphorus in the degenerated side of the cord, which stained by the Marchi reaction.

The President said that Professor Halliburton had spoken of "clouds" overhead in the sky of psychology, but they had let fall many "rain-drops" that afternoon. An important practical outcome from these researches was the possibility of discovering the difference between organised brain degeneration and functional troubles, choline being absent in hysterical paralysis and present in organic degeneration of brain tissue. They offered their hearty congratulations and thanks to Professor Halliburton; their sympathy with Dr. Mott on his illness, and their regret that he was not able to be with them that day. They fully appreciated the compliment to the Association in this early presentation of a preliminary report upon work of the greatest value.

Professor Halliburton, in reply to Dr. Seymour Tuke, said the test was most evident during and after the convulsive seizures in general paralysis.

Dr. Bolton gave a lantern demonstration upon "The Morbid Changes in Dementia" (see p. 330).

The President proposed a vote of thanks from the members of the Association to the Asylum Authorities for allowing them to meet there, and for the courtesy received. This was unanimously agreed to.

Dr. Robert Jones, on behalf of the Authorities of the Asylum, thanked the President and members for their kind expressions, and promised to convey the resolution to his Sub-Committee.

Members afterwards dined together at the Café Royal, Regent Street.

\section{Council Meeting.}

Present: Drs. Fletcher Beach (President), H. Hayes Newington (Treasurer), Harry A. Benham, A. R. Urquhart, G. Stanley Elliot, R. Percy Smith, H. Gardiner Hill, James Chambers, L. A. Weatherly, J. Carlyle Johnstone, A. W. Campbell, A. N. Boycott, H. T. S. Aveline, and Robert Jones (Hon. General Secretary).

Apologies for non-attendance were received from Drs. Savage, Crochley Clapham, Rayner, Bond, Oscar Woods, Mercier, Miller, Spence, Finegan, Ernest W. White, Turnbull, and Macdonald.

Inter alia the Treasurer reported a credit balance of $£ 485$ 17s. 2d., and stated that the affairs of the Association were apparently more prosperous than at the same date last year.

The Secretary was instructed to prepare a set of Rules of the Association, showing what changes had been made since they were last printed, so that the annual meeting should be asked to give instructions for reprinting.

The Library Committee was constituted as follow:-Drs. Beach, Rayner, Outterson Wood, and Macevoy.

The following were appointed delegates to represent the Association at the British Congress on Tuberculosis:-Drs. Weatherly and France; and 6 Io ros. was voted for the purposes of the Congress.

Dr. Taylor's (Darenth) application for admission of candidates to the nursing examination was approved.

It was agreed that the Annual Meeting should be held at Cork on July 25th and 26th. 
The following Committee was appointed to consider and report on the formation of Colonial branches :-Drs. Beach, Hayes Newington, Urquhart, and Robert Jones.

\section{THE EDITORSHIP OF "BRAIN."}

The Annual Meeting of the Neurological Society was held at I1, Chandos Street, on February 14th, the meeting having been postponed from the date originally fixed, on account of the death of Her Majesty Queen Victoria. The address was given by the in-coming President (Dr. W. Julius Mickle) on the subject of "Mental Wandering." The most noteworthy change in the list of officers of the Society is the disappearance of the name of Dr. A. de Watteville from the editorship of 'Brain,' the journal of the Society. With reference to this the Council make the following remarks in their report:

"It is with great regret that the Council announces that Dr. A. de Watteville has resigned the Editorship of 'Brain.' When accepting his resignation, the following resolution was unanimously adopted:-The Council accepts with great regret Dr. de Watteville's resignation of the Editorship of 'Brain,' and desires to take this opportunity of recording the deep debt of gratitude that the Society owes him for the way in which he has conducted the Journal for the past twenty years. The Council feels that parting with Dr. de Watteville is an event of great moment to the Society, for he has not only brought 'Brain' to a high standard of perfection, and secured for it a great European reputation; but even the existence of the Journal at the present time is due to his energetic action at a critical juncture in 1880 . Moreover, the Council is mindful that the Society itself took origin on Dr. de Watteville's initiative, at a meeting held at his house, on November 14th, 1885."

We are sure that our readers, many of whom are members of the Neurological Society as well as of our own Association, will fully endorse the regret expressed above. The task of Editorship is very materially lightened for the future by the reputation secured to 'Brain' by Dr. de Watteville's labours in the past, and we may express the hope that it will still be maintained. The new Editor is Dr. Percy Smith, who will be assisted in the selection of papers by a Committee.

\section{THE CONSTRUCTION OF ASYLUMS.}

ON February 18th, at the Royal Institute of British Architects, Mr. George T. Hine, F.R.I.B.A., contributed an interesting paper on "Asylums and Asylum Planning." In the course of his address, which was read by Dr. HAYES Newington, he said :

Asylums were built for people who had to be watched, nursed, and provided with employment and recreation under conditions inapplicable to sane people, and to provide for all these, while the subjects were under detention, a special knowledge was required to make their lives bearable, and, as far as possible, pleasurable.

Existing types of plan were all more or less developments of the corridor and pavilion systems. In the early days the corridor system, consisting of a long gallery, with single rooms opening out of it, was the only recognised principle on which an asylum could be built. The form was usually quadrilateral. After 1845 , while the internal arrangements savoured less of restraint, the principle of the corridor system still prevailed. The first development was an attempt at classification by the introduction of a ward for the sick and infirm on each side of the building ; the number of cells was reduced, and more patients were allowed to sleep in associated dormitories. In the seventies special provision began to be made for epileptics, and the Lunacy Commissioners in 1874 published a plan, designed by Mr. Howell, for an epileptic ward, which had been adopted with trifling variations in nearly every asylum designed within the last twenty years. In the decade 1871-80 the pavilion system came into vogue, the transition stage being represented by the asylum at Whittingham. Architects designing asylums should give first consideration to the site. In many of the plans coming under his official 